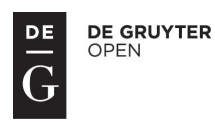

\title{
Tax Policy Assessment in Slovenia - Case of Interest TAX SHIELD
}

\author{
Tatjana Jovanović $^{1}$, Maja Klun ${ }^{2}$
}

\begin{abstract}
The tax policy assessment is an indispensable strategy within any modern country's system of governance. There are several types of "impact assessments", with RIA as one of the most commonly used. This tool is used to measure and analyse the benefits, costs and effects of a new or existing legal regime, which can be carried out by collecting and analysing empirical data in the context of a broader decision-making framework. The main objective of the paper is to analyse which stage the Slovenian regulatory impact assessment is in, and whether this stage is sophisticated enough to provide for the essential verification of tax policy and specific instruments, focusing mainly on the case of interest tax shield issues. Methodologically, the paper is based on a systematic literature review, a survey for public consultations and statistical tools for calculating the differences in internal indebtedness in different observed periods. The results show that the Slovenian RIA is not sophisticated enough to evaluate complex tax instruments and policy. Nevertheless, tax policy decision-makers should reconsider the implementation of a thin capitalization rule (but also future tax policy instruments) focusing also on other, non-tax revenue, factors.
\end{abstract}

\section{Keywords}

$\underline{\text { Regulatory Impact Assessment, Tax Policy, Thin Capitalisation, Multinational Companies }}$

\section{Introduction}

The globalisation of the world economy occurred due to the increased mobility of individuals and financial transactions. Consequently, businesses and individuals enjoy a greater supply of various types of goods and services; they can also choose from among several different locations for their investments and between different places of employment and retirement. The world's globalization affects the whole area of economic policy, with

\footnotetext{
${ }^{1}$ University of Ljubljana, Faculty of Administration, Gosarjeva ulica 5, SI-1000 Ljubljana, Slovenia. E-mail: tatjana.jovanovic@fu.uni-lj.si.

${ }^{2}$ University of Ljubljana, Faculty of Administration, Gosarjeva ulica 5, SI-1000 Ljubljana, Slovenia. E-mail: maja.klun@fu.uni-lj.si.
} 
strong influence on national tax systems. These effects can be observed in terms of geographically more mobile tax bases for income and wealth taxes, more sensitive behaviour among highly educated individuals as generators of economic development as far as differences between tax systems are concerned, several difficulties in calculating and collecting taxes on activities that take place beyond national jurisdiction and strongly changing tax administration activity models as new technologies open up ${ }^{3}$.

The several advantages arising from globalization cannot hide the even more numerous problems governments have to face in regard to regulation of the national tax system. These are competitiveness, tax evasion and avoidance, tax competition and the transnationalisation of the tax base, which governments have to fight at the national level as well as at the level of the worldwide economy. This is only possible in an adequate legal environment. The legal environment depends on legislation, which in the context of multinational companies sets the rules for market competition and unique operating conditions. Inappropriate legislation (not only with regard to taxation) overwhelms the requisite frameworks and can be administratively burdensome, inexcusably costly and even counterproductive. Administrative burdens are an administrative expense incurred solely due to the requirements of regulation and not due to the normal costs of business. Legislation is important and necessary, but may cause additional, unnecessary compliance costs, which represent an additional burden on businesses and an unnecessary loss of valuable time and, consequently, competitiveness. Rapid technological developments, the opening and expansion of global markets and increasing access to information mean that legislation needs to be constantly reviewed and updated if a country and its market are to keep pace with a rapidly changing world ${ }^{4}$.

The main idea of the paper is to present the development stage of Slovenian legislative procedures, especially focusing on preliminary impact assessment of the tax legislation affecting companies operating multi-nationally. In the last decade, we have witnessed many and rapid changes in Slovenian tax legislation, sometimes even reforms, while the effects of those have been analysed neither ex-ante (preliminary) nor ex-post (later). Several of them have been the result of tax policy coordination within the European Union (EU) (Kouba et al., 2016). In addition to the strictly settled objectives of each respective legislation change, the legislator's main objective in the field of corporate income taxation should be to increase international economic efficiency and the tax neutrality of international tax policy ${ }^{5,6,7}$. The concept of efficiency assumes that productivity rises with production factor distribution within market mechanisms, provided governments do not intervene. While neutral tax legislation does not interfere with production factor distribution, it is impossible to achieve truly neutral tax legislation. The challenge facing tax policy should be to achieve the highest possible degree of neutrality. The efficiency objective can be achieved without the neutrality condition.

\footnotetext{
${ }^{3}$ Owens (1998).

${ }^{4}$ European Commission (2006).

${ }^{5}$ Hufbauer (1975).

${ }^{6}$ Musgrave (1969).

${ }^{7}$ Musgrave (2002).
} 
Focusing on the main objectives of the article, the research questions are:

- In which stage is the Slovenian methodology (procedure) for regulatory impact assessment?

- Is this stage sophisticated enough to facilitate the essential verification of the advisability of specific tax instruments, such as the interest tax shield?

To achieve its main objectives, the paper will focus on a systematic literature overview, then a survey analysis and finally the use of statistical tools (SPSS - Friedman and Wilcoxon test).

The article is divided into five sections. After the introductory part, a literature review on regulatory impact assessment is presented in the second part. The third part focuses on the Slovenian methodology for assessment of the regulations, while the fourth part empirically evaluates the advisability of the interest tax shield instrument in Slovenia. The fifth section evaluates the results of the research and concludes the paper.

\section{Literature review}

Tax policy necessitates an appropriate methodology for the analysis and assessment of the impacts of tax instruments within tax regulation. Adequate tax policy is an even greater challenge in the case of multinational companies operating in several jurisdictions. They are obligated to respect two or more legal (tax) systems as far as profit taxation is concerned: the legal system of the country in which they permanently operate and the legal system of the resident country ${ }^{8}$. For multinational enterprises, tax implications represent a key factor in decisions on whether to invest in a country. Research to date in the field of taxation of the profits of multinational enterprises (multinationals) has shown that in many respects multinationals are mobile and able to avoid taxes. Legislators or politicians involved in measuring the appropriate level of tax revenue in an individual country are therefore inclined to limit opportunities for tax planning ${ }^{9,10}$. Therefore, policymakers are forced to protect national tax revenues and simultaneously attract foreign direct investment (companies), which complicates the situation. They implement various measures to prevent a longer-term effect in the form of tax competition ${ }^{11}$. National legislators use two instruments to avoid the up to now observed profit shifting of multinational firms. On the one hand, tax competition has led to a significant decrease in corporate tax rates ${ }^{12}$, and on the other hand, countries, typically large and high-tax examples, have implemented anti-avoidance rules in order to prevent profit shifting ${ }^{13}$.

Adequate tax regulation evidently requires a balanced approach between the successful attraction of foreign direct investments and protection of public finances in the form of anti-avoidance rules. Namely, policy instruments are carriers of causal ideas and economic

\footnotetext{
${ }^{8}$ Kovač (2009).

${ }^{9}$ Wamser (2014).

${ }^{10}$ Weichenrieder (2009).

${ }^{11}$ Jovanović (2014).

${ }^{12}$ Ramb \& Weichenrieder (2005).

${ }^{13}$ Weichenrieder (2009).
} 
theories used and adopted by the legislators, who are socialized into ways of seeing policy problems through certain cognitive and normative lenses. The reason for that derives from the fact that policy instruments are contingent on presuppositions and conjectures about the relationship between public policy and the economy ${ }^{14}$. Accordingly, effective policy-making and thus tax regulation necessitates effective mechanisms that can facilitate preliminary impact assessment of planned tax instruments. Similar ideas have been present in the EU since the second half of the 1990s. They have been promoting the diffusion of institutions and policy instruments that enable governments to assess and manage regulation in different fields through the entire life cycle, including outcomes and long-term impacts. In order to achieve this aim, such approaches must contain well-developed metrics, usually in the form of benchmarks and standards that can demonstrate the quality of the proposed policies independently of the policy field ${ }^{15}$.

All of the above represents the reason that countries are facing a great challenge in creating an approach or methodology for efficient and effective policy assessment and policy-making. Evidence-based policy-making is one of the latest policy-planning approaches, widely applied in public administration ${ }^{16}$. Policy assessment is most commonly practiced as one of several types of "impact assessments" that have emerged in the last two decades, such as regulatory impact assessment (RIA), sustainability impact assessment (SIA) and simply impact assessment (IA). There are slight differences among them, especially in terms of objectives and relevant impacts, but the terms are often used interchangeably, creating some confusion. These broad types of policy assessment in turn harness a range of policy assessment tools and methods, such as cost-benefit analysis (CBA), scenario analysis and computer modelling. The idea of policy assessment has spread rapidly around the world in the last two decades, while in the 1990s there were only a few OECD countries using it. Since 2008, the number of countries using this concept has increased to 31 countries that have either adopted or are in the process of adopting it $^{17}$. Policy assessment systems (in the form of RIA, SIA and IA) have become a part of legal procedure in almost every European Union (EU) member state and in countries as far apart as the USA, Australia and South Africa, with the systems in different countries varying enormously in their design, implementation and even purpose. Nevertheless, it is important to emphasize that the procedure in some countries exists only on paper and is poorly implemented in practice. The most recent countries to start using policy assessment procedures are Estonia and Lithuania $^{18}$.

The most recent studies of policy assessment procedures ${ }^{19}$ among world countries show that RIA is being applied in a number of developing and emerging economies, but is not well institutionalized. Developed countries, such as Germany, the Netherlands, Sweden and the UK, have set the agenda for this regulatory innovation since the 1980s, with some forms

\footnotetext{
${ }^{14}$ Morgan (2003).

15 Coletti \& Radealli (2013).

16 Petak (2015).

17 OECD (2009).

18 Adelle \& Weiland (2012).

${ }^{19}$ Adelle et al. (2016).
} 
of compliance cost assessment, while for the majority of European Union member states, the move towards RIA has accelerated in recent years ${ }^{20}$. Focusing on OECD countries, the number has grown between 1974 and 2012, and 33 countries have begun using the system. At the same time, the countries involved admit that implementation is demanding from both an administrative and technical perspective ${ }^{21}$.

RIA is therefore one of the most common and essential tools for analysing the quality of legislation and/or evaluating the impact of regulations. The general goal of assessing regulation impacts is to assist governments by facilitating ex-ante evaluation of the potential impacts of policies on all stakeholders, more effective implementation of sector-specific policies and a holistic projection of the long-term impacts of policies. RIA is used to provide an overview and measurements of the likely benefits, costs and impacts of new or existing regulation. Analysis, evaluation and assessment of regulation impacts produced in line with the RIA methodology offers comprehensive support for the policy-making process, as RIA uses the following elements to assess the impacts of regulations ${ }^{22}$ :

1) Empirical analysis - Decisions are conceptualized around facts and analyses which determine parameters for action in accordance with certain metrics

2) Expert groups - Decisions are based on the professional opinions of trustworthy experts

3) Agreement among stakeholders - Decisions are reached in collaboration with interested parties, who seek common ground that would balance out their interests

4) Political consent - political representatives search for solutions or decisions on the basis of the priorities of politically set objectives

5) Comparative analysis - the decision is based on a comparison with external models such as systems in other countries

Each decision in the policy-making process stems from a combination of the decision-making methods listed above. The combination of elements used differs from country to country, in line with national culture, political traditions, administrative systems and current socio-political developments. The decision-making framework provided by RIA includes multiple methods that at their core are experience-based. The role of RIA in the policy-making process is therefore to surpass the narrow framework of formal empirical methods; in line with its nature, RIA can make an important contribution to other methods used to support decision-making when designing different kinds of public policies. The elements (methods) listed above must be mutually complementary, as none of them independently provide adequate support for public policy-making. The effective integration of the elements of RIA and their purposeful use in the decision-making process can facilitate fact-based decision-making, improve the inclusion of affected stakeholders in public discussions and the decision-making process, ease the inter-agency harmonization of policies and constitute a foundation for the use of alternative methodological approaches to evaluating planned policies and their effects ${ }^{23}$.

\footnotetext{
${ }^{20}$ Francesco et al. (2012).

${ }^{21}$ OECD (2015).

22 OECD (1997).

${ }^{23}$ OECD ( 2008).
} 
Generally, there is a lack of theoretical knowledge about planning and preparation procedures for tax legislation assessments, and there are almost no studies that specifically report the tax policy assessment in any country. The exception we found was a study on impact assessment of measures in the field of taxation in Great Britain. In 2012, the UK adopted a special tax policy focusing on making legislation in this field competitive, simpler, mindful of the environment and fair. The research results for the period 2010-2013 show that one third of the changes in tax legislation did not contribute to any of the stated objectives; one fourth of the changes led to greater fairness, while a mere fifth addressed simplification. Additionally, the study showed that competitiveness did improve, while the environmental aspect is covered by only $7 \%$ of the changes ${ }^{24}$.

Although RIA does not provide a standalone tool for supporting the decision-making process, findings gained through its use can shed light upon an important trend in designing and steering public policies. Conclusions arrived at on the basis of RIA are all the more important if adequate prior analysis was conducted when selecting suitable methods in the framework of RIA for evaluating individual policies and their impacts ${ }^{25}$. The point is not the "ideal" tax legislation structure, but rather ascertaining the efficiency and necessity of processes for tax legislation creation through assessments of effects on the various segments of the social environment. In some OECD countries, this process has become a complex ritual involving various interested groups, which aim to create their own vision for tax policy through tax legislation. In developed countries, the process involves inter alia professional lobbyists, political analysts, lawyers, consultants and accountants, while in developing and transition countries, it is carried out with fewer interested parties. Both formats have their advantages and disadvantages. A small group of highly qualified people can do a better job of creating relatively harmonized legislation, but the lack of institutionalized experience in tax law may mean that the process will not be smooth and will not include adequate consultation with experts at each step. Adequate research support must be provided to experts involved in the process, with the research encompassing three key areas: (1) an assessment of tax revenues, (2) research or analysis of the current situation and (3) comparative analysis of the organization ${ }^{26}$.

All of the above-mentioned areas have to be addressed very precisely in national tax policy assessment procedures. When considering the first area (tax revenues), national legislators pay special attention to companies operating multi-nationally. This can be nicely presented in the example of the previously mentioned tax shield instrument. The fact is that an equally important element in the tax planning of multinational enterprises is their ability to structure finances in terms of capital and debt, not only for the enterprise as a whole, but also within the group. Aside from the direct loss of revenue, increasing the opportunities for tax savings gives multinational enterprises advantages with respect to enterprises that only do business at the national level. The interest tax shield phenomena launched the introduction of the so-called thin capitalisation rule that generally denies (i.e. does not recognise for tax purposes) interest expenses for internal loans if the debt-to-

\footnotetext{
${ }^{24}$ Bradley (2015).

${ }^{25}$ Radaelli \& Francesco (2008).

${ }^{26}$ Thuronyi (1998).
} 
-capital ratio or the amount of interest exceeds a specific limited threshold, i.e. is actually spreading ${ }^{27}$. The literature indicates that those rules (thin capitalisation rules) are effective at limiting internal borrowing ${ }^{28,29}$. This has been proved particularly to be the case for Germany, although it remains unclear whether tax revenues are simultaneously growing. Based on this knowledge, our further research will concentrate on the Slovenian case of tax policy assessment, especially considering the tax shield instrument.

\section{Tax policy assessment in Slovenia}

The beginnings of policy and legislation assessment in the Republic of Slovenia are connected with a systemic approach to the reform process in the field of public administration. The Slovenian assessment concept is based on RIA, which was first mentioned in the Programme for Effective Accession to the European Union and also in the Strategy for the Continuous Development of the Slovenian Public Sector 2003-2005 (it also appears in the most recent version of this strategy, for the 2015-2020 period). The historical overview of activities in the field of RIA shows that over the past decade a fair amount of progress has been made in the direction of introducing assessments of effects or impacts of regulation; in particular, much has been done to remove administrative hurdles. On a negative note, elements of RIA are dispersed throughout multiple legal acts, the breadth of the analysed impacts is too extensive and there are no precise instructions for conducting analyses of impacts or effects. The link between impact assessment and public participation in the decision-making process is also deficient, as it is not addressed systemically ${ }^{30}$.

Nevertheless, the Government program of measures to eliminate administrative barriers and the Rules of Procedure of the Government ${ }^{31}$ were implemented in 2005 and 2006. The RIA concept did not get off the ground in reality until 2009. The reason for that was a lack of knowledge about the content and meaning of the assessment system as well as the absence of umbrella legislation in the RIA field. There were some cases of more intuitive assessment, but no systematic methodology of data collection and evaluation, decision-making basis, or techniques of including the public in the decision-making process existed. Declaratively and legislatively, through the Rules of Procedure of the National Assembly of the Republic of Slovenia, the manual for the planning, management and evaluation processes of public participation, the handbook for assessments of the effects of regulations and policies, the e-democracy portal, etc. the RIA concept was implemented, but due to the

\footnotetext{
${ }^{27}$ Haufler \& Runkel (2012).

${ }^{28}$ Overesch \& Wamser (2010).

${ }^{29}$ Buettner et al. (2012).

${ }^{30}$ Rakar (2005).

${ }^{31}$ It determines the following elements when submitting a new law or an amendment: assessment of the current state and reasons for amending the law; objectives, principles and key solutions of the draft law; assessment of the financial impacts of the draft law on the state budget and other public financial resources; a statement that funds for executing the law are available in the state budget, insomuch as the draft law foresees the use of budget funds in a period for which a budget has already been adopted; a presentation of how the field is handled in other legal systems and of the compatibility of the proposed legislation with the laws of the European Union, which must contain solutions from the legal systems of at least three European Union members; and other impacts that the adoption of the law would produce.
} 
lack of umbrella regulation of RIA, there was neither a basis nor measurement of the implementation thereof.

After some pressures from OECD connected with full membership, in 2009 and 2010 Slovenia adopted the Resolution on Legislative Regulation, the amendment to the Rules of Procedure of the Government and the implementing instructions or information support for RIA. It looked like a great step towards more systematic and hierarchical methodology, but the results, observed from a practical, not declaratory level, were not much of an improvement ${ }^{32}$.

There are no specific analyses of the impact assessment for tax regulations and policy in Slovenia. Nevertheless, the Court of Audit of the Republic of Slovenia researched the level of the impact assessments in Slovenian legal order in 2007 and 2012, focusing on the following criteria: (1) assessment of financial impacts of the draft law; (2) issuance of opinions on the assessment of the financial impacts of the draft law; (3) checking for any other foreseen impacts of the draft law; and (4) public participation in the process for preparing the draft law. As far as the first criteria is concerned, an assessment of financial impacts on the state budget and other financial resources was provided for $86.21 \%$ of all draft laws in 2004, while in 2005 it was provided for $97.78 \%$ of draft laws. In 2012, in $61.7 \%$ of all cases, the legislator presented some financial impacts of the proposed law. The Court's research additionally shows that other impacts were assessed in just $30 \%$ of cases in the form of a general description. A very interesting research finding was that the proposers often claimed (41.67\% of proposed laws in 2004, $61.36 \%$ of proposed laws in 2005) that a law would not have any other impacts whatsoever, i.e. that it was not expected to impact the environment, the economy or social security. Regarding criteria for the inclusion of individuals and other interested groups, it turned out that in the majority of cases, the legislator does not keep statistics on hits on the website for draft laws or on responses to published draft laws ${ }^{33,34}$. The results for the later period show that the legislator did not list other impacts in $4.6 \%$ of cases, and in $54.2 \%$ of cases there were no other foreseeable impacts, while in general it presented no essential progress in evaluation of the impacts.

As far as tax regulation in Slovenia is concerned, the procedure of regulation assessment does not differ from other legislation procedures and criteria assessed. In Slovenia, the Ministry of Finance as the proposer of the tax legislation is usually confronted with very short deadlines and very often politically dictated changes, even reforms of legislation. The consequences are evident: badly planned tax policies, volatility and unpredictability of tax system, frustrated taxpayers, etc. All of those negative consequences are specifically harmful when considering foreign companies operating in our national economy. Tax policies clearly have an impact on foreign direct investment through a number of factors, but the weight of this impact is questionable. There was no research done for Slovenia to analyse the factors and conditions for the appropriate FDI-attracting tax policy that would protect national tax revenues on one side and keep the country tax competitive on the other.

\footnotetext{
${ }^{32}$ Kovač (2011).

33 Court of Audit (2007).

${ }^{34}$ Court of Audit (2012).
} 
The previous research has shown that tax structure is an even more important indicator of the tax burden than GDP ratio as far as FDI attraction is concerned, while policy makers should evaluate and analyse the continuity of taxes, transparency of the system for determining the tax base, enforcement of payment of tax revenue, independence of the judiciary in administrative disputes involving decisions of the tax authority, a network of international agreements on the prevention of double taxation, etc. ${ }^{35}$

Finally, we can conclude our research on RIA procedure development by identifying several problems in terms of the practical use of RIA, which is, at a declaratory and theoretic level, very precisely regulated but is much more loosely determined. Consequently, the RIA concept is at a relatively low development stage far as policy assessment is concerned.

\section{Impact assessment of anti-avoidance tax instruments in Slovenia}

To present and support the above-mentioned claim, we are going to analyse one of the tax instruments for the elimination of the interest tax shield. The interest tax shield is the amount of tax savings on profit due to interest, which is tax deductible when calculating the tax base for corporate income tax. Debt financing, unlike equity-financing, influences the tax base through tax-deductible interests. The interest tax shield encourages businesses, especially those operating in groups within the various countries, to seek such a financial structure within the group that relieves group units in countries with high income tax rates. Consequently, tax administrations are forced to protect the tax base and tax revenues regulating anti-avoidance thin capitalization rules. The thin-capitalization rules monitor the interests charged between related parties or the amount of loans on which interest is charged. In the last decade or two, many countries have introduced various forms of thin capitalization rules, and this is also the case for Slovenia.

The Slovenian thin capitalisation rule of 2005 stipulated that interest on loans ${ }^{36}$ received from a shareholder or partner who at any point in the tax period directly or indirectly held no less than $25 \%$ of the shares or holdings in the capital or voting rights of the taxable person, provided that the loans in question exceeded, at any point in the tax period, four times the amount of the holding of the shareholder or partner in the taxable person's capital (the surplus of the loans), established with regard to the amount and duration of the surplus of the loans in the tax period, would not be recognised as an expense unless the taxable person provided evidence that it could have obtained the surplus of the loans from a non-affiliated lender. Loans extended by a shareholder or partner also include loans extended by third parties, including loans extended by banks that are guaranteed by the shareholder or partner in question, or when the loans are obtained in connection with a deposit held in that bank by the shareholder or partner in question. The amount held by a shareholder or partner in the capital of the recipient of a loan shall be determined for the tax period as an average on the basis of the balance of paid-up capital, net profit brought forward and reserves as at the last day of each month in the tax period. Qualified

\footnotetext{
35 OECD (2003).

${ }^{36}$ Excluding cases involving borrowers that are banks and insurance companies.
} 
participation was fixed at four times the amount of the holding of this shareholder or partner in the capital of the taxable person (ZDDPO-1, Official Gazette of the Republic of Slovenia, 33/06 - consolidated version, of 30 March, 2006), while in the transitional provisions the Act stipulated eight times the amount for 2005, six times the amount for 2006, 2007 and 2008 and five times the amount for $2009^{37}$.

Our main objective was to prove the effectiveness (ineffectiveness) of this rule in Slovenia, while the legislator's Corporate Income Tax Act impact assessment was very poor, not to mention the lack of overall tax policy as far as FDI are concerned. The proposed changes to rules on thin capitalization were also very general and do not include all the elements listed in the Rules of Procedure. In the explanation of the proposed legislation of corporate income tax, the proposers only clarified the meaning of the instrument and did not give reasons for the change or list expected impacts. Based on the theory of legislative planning and preparation, the assessment of the thin capitalization tax instrument was found to be lacking (at the very least) in its analysis of practices to date and the current situation, and, consequently, in its assessment of impacts on the budget. The assessment did, however, include comparisons with other countries. The research to date from throughout the world has shown that the base variable or parameter - internal debt of companies - decreases due to tightening of the thin capitalization rules, which means that thin capitalization is an effective instrument for limiting debt financing. These findings motivated us to empirically analyse the case of Slovenian thin-capitalization instrument implementation.

But before presenting our analyses of the thin-capitalization instrument in Slovenian tax law, we have focused on one of the most important RIA elements - public consultation. We have addressed this element of RIA by asking interested parties. The survey was send to three different groups of experts: academics, tax advisors and civil servants who work in the field of taxation (tax administration and ministry of finance). The survey was carried out in 2015. Out of 168 replies, 12 were from academics, 55 from the private sector ( 27 tax consultants, 21 accountants, 1 auditor and 4 others) and 101 from the public sector (only one was from the Tax Authority). Among several other questions, respondents were asked to express their opinion about the statement "The tax rule in Slovenia for preventing the interest tax shield is adequate." The results of the survey show that $58 \%$ of all respondents agreed ( $42 \%$ did not) with the statement. Focusing on responses by sectors, the differences are obvious. Only $34 \%$ of the public sector representatives agreed, compared to $76 \%$ of private sector representatives and $80 \%$ of academics.

Additionally, we extended our research from a qualitative to a quantitative analysis. Our statistical analysis presents the case of impact assessment of the specific tax policy the instrument of thin capitalization. While the literature indicates that thin-capitalization rules (TCRs) are effective at limiting internal borrowing, we were interested if that was the case in Slovenia as well. We decided to analyse data for all 666 companies operating in Slovenia and with a foreign ownership share of no less than $25 \%$ in the capital of the taxable person (associated enterprises). The data were obtained from the annual financial reports collected by the Agency for Public Legal Records and Services (AJPES). While

${ }^{37}$ ZDDPO-2, Article 81. 
we were interested in testing the differences in indebtedness by the criterion of capital origin, we have first classified the number of companies by the origin criteria.

Figure 1: The number of enterprises by the criterion of capital origin

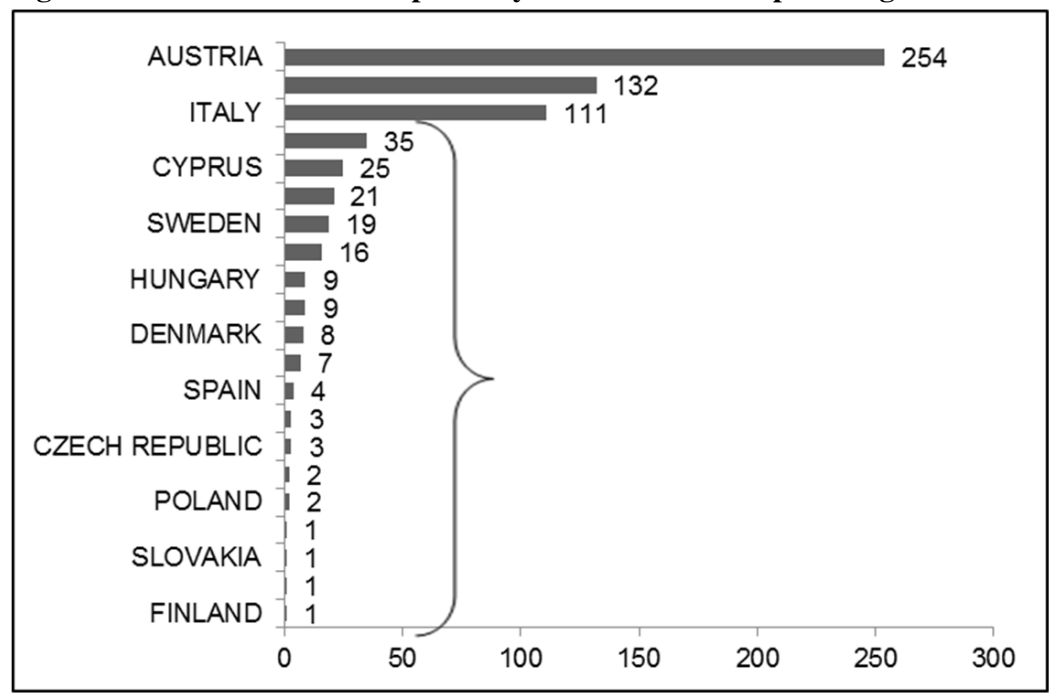

Source: own (2016)

Figure 1 presents the number of companies by the capital origin counties in our sample. It turned out that for almost $75 \%$ of companies, the country of origin is Austria, Germany or Italy, while the group of "others" consists of companies with another country of origin. For the companies in our sample, we have focused on the variable "internal debt", which presents the obligations of subsidiary companies (operating in Slovenia) to parent company, operating abroad. The analysis included data for the years 2003, 2004, 2009, 2010, 2012 and 2013 using a two-year average (2003 and 2004, 2009 and 2010, 2012 and 2013) for each period of the comparison. Variable - internal debt consists of long-term and short-term loans and the two-year average variables are labelled as ID0304, ID0910 and ID1213. In the first step, the descriptive statistics were calculated, which did not show any special features. The next step was the test of statistically significant difference in internal corporate debt in the periods 2003/04, 2009/10 and 2012/13 by the criterion of capital origin. 
Figure 2: The average internal debt and number of units in the sub-sample in the observed period and according to capital origin

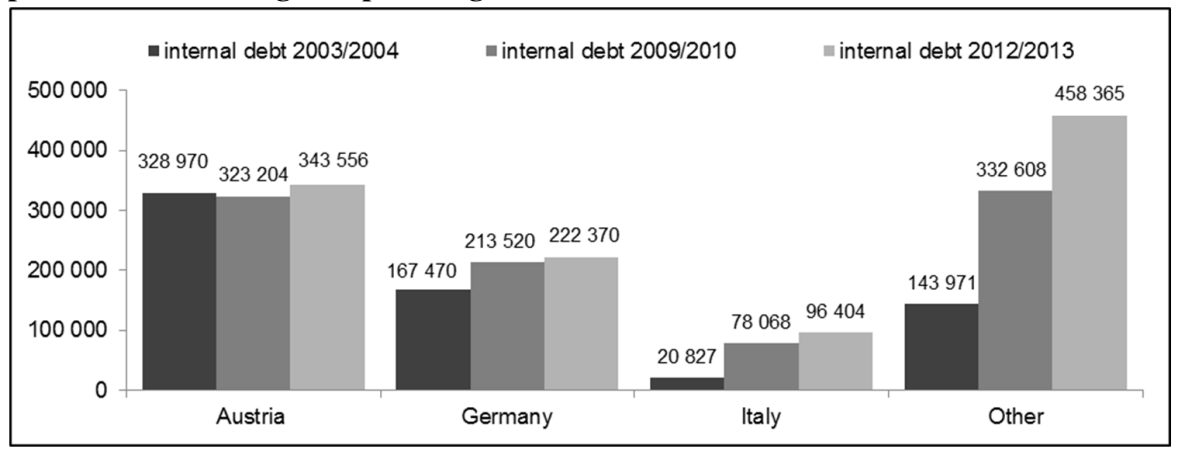

Source: own (2016)

According to Figure 2, the internal debt of the enterprises in the sample in the observed period has on average increased in the observed period by the criterion of capital origin. The exceptions are enterprises whose ownership is from Austria. The internal debt of those decreased in the periods 2003/04 and 2009/10, but again increased on average in the period 2012/13 and exceeded the indebtedness of the measurement period 2003/04. Nevertheless, the tax policy instrument has limited the amount of internal indebtedness in the year 2005, while the internal debt of companies on average increased. To prove the statistical significance of those differences, the Friedman test was carried out to verify if the differences are statistically significant in any of three periods. The results (Table 1) confirmed that the differences in internal debt of the enterprises by the criterion of capital origin are not statistically significant, which leads us to the conclusion that an increase in internal debt in most companies does not deviate from the average to the extent that we can speak of typical deviations.

Table 1: The results of the Friedman test - the differences in internal debt in the periods measured in relation to the origin of capital

\begin{tabular}{|l|c|c|c|c|c|c|}
\hline \multicolumn{2}{|c|}{} & Average (€) & $N$ & $\chi^{2}$ & $d f$ & Sig. \\
\hline \multirow{4}{*}{ Austria } & ID0304 & 328,970 & 217 & 0.848 & 2 & 0.655 \\
& ID0910 & 323,204 & & & & \\
& ID1213 & 343,556 & & & & 0.141 \\
\hline \multirow{4}{*}{ Germany } & ID0304 & 167,470 & 115 & 3.919 & 2 & \\
& ID0910 & 213,520 & & & & \\
& ID1213 & 222,370 & & & & \\
\hline \multirow{3}{*}{ Italy } & ID0304 & 20,827 & 110 & 1.258 & 2 & \\
& ID0910 & 78,068 & & & & \\
& ID1213 & 96,404 & & & & \\
\hline
\end{tabular}

Continued on next page 
DOI: 10.1515/danb-2017-0001

\begin{tabular}{|l|c|c|c|c|c|c|}
\hline \multicolumn{2}{|l|}{ Other } & Average (€) & $N$ & $\chi^{2}$ & $d f$ & Sig. \\
\hline \multirow{3}{*}{$N$ ID0304 } & 143,971 & 145 & 4.312 & 2 & 0.116 \\
& ID0910 & 332,608 & & & & \\
ID1213 & 458,365 & & & & \\
\hline
\end{tabular}

Source: own (2016)

Nevertheless, the analysis was upgraded (Wilcoxon test) to verify the change in internal corporate debt in relation to the origin of the capital in two specific periods measured. It turned out (Table 2) that the differences in internal debt of enterprises with Austrian, German and Italian capital origin by different (par of) periods were not statistically significant. The only exception was the increase of internal debt for German enterprises for the periods $2003 / 04$ and $2012 / 13(z=-2.473 ; p<0.05)$, which is statistically significant. The internal debt of companies labelled under "others" has increased in the observed periods, but the increase was not statistically significant in the periods 2003/04 and 2009/10 and in the periods $2009 / 10$ and 2012/13. A statistically significant increase in internal debt appeared in the periods 2003/04 and 2012/13 ( $z=-2.191 ; p<0.05)$.

Table 2: The results of the post-hoc (Wilcoxon) test of the differences in the periods observed in relation to capital origin

\begin{tabular}{|c|c|c|c|c|c|}
\hline & & & ID0304 & ID0910 & ID1213 \\
\hline \multirow{6}{*}{ Austria } & \multirow{2}{*}{ ID0304 } & $\mathrm{Z}$ & & -1.081 & -1.380 \\
\hline & & Sig. & & 0.280 & 0.167 \\
\hline & \multirow{2}{*}{ ID0910 } & $\mathrm{Z}$ & -1.081 & & -0.549 \\
\hline & & Sig. & 0.280 & & 0.583 \\
\hline & \multirow{2}{*}{ ID1213 } & $\mathrm{Z}$ & -1.380 & -0.549 & \\
\hline & & Sig. & 0.167 & 0.583 & \\
\hline \multirow{6}{*}{ Germany } & \multirow{2}{*}{ ID0304 } & $\mathrm{Z}$ & & -1.731 & -2.473 \\
\hline & & Sig. & & 0.083 & 0.013 \\
\hline & \multirow{2}{*}{ ID0910 } & $\mathrm{Z}$ & -1.731 & & -1.057 \\
\hline & & Sig. & 0.083 & & 0.291 \\
\hline & \multirow{2}{*}{ ID1213 } & $\mathrm{Z}$ & -2.473 & -1.057 & \\
\hline & & Sig. & 0.013 & 0.291 & \\
\hline \multirow{6}{*}{ Italy } & \multirow{2}{*}{ ID0304 } & $\mathrm{Z}$ & & -1.420 & -1.396 \\
\hline & & Sig. & & 0.156 & 0.163 \\
\hline & \multirow{2}{*}{ ID0910 } & $\mathrm{Z}$ & -1.420 & & -0.094 \\
\hline & & Sig. & 0.156 & & 0.925 \\
\hline & \multirow{2}{*}{ ID1213 } & $\mathrm{Z}$ & -1.396 & -0.094 & \\
\hline & & Sig. & 0.163 & 0.925 & \\
\hline
\end{tabular}




\begin{tabular}{|c|c|c|c|c|c|}
\hline & & & ID0304 & ID0910 & ID1213 \\
\hline \multirow{6}{*}{ Others } & \multirow{2}{*}{ ID0304 } & $\mathrm{Z}$ & & -1.245 & -2.191 \\
\hline & & Sig. & & 0.213 & 0.028 \\
\hline & \multirow{2}{*}{ ID0910 } & $\mathrm{Z}$ & -1.245 & & -0.293 \\
\hline & & Sig. & 0.213 & & 0.769 \\
\hline & \multirow{2}{*}{ ID1213 } & $\mathrm{Z}$ & -2.191 & -0.293 & \\
\hline & & Sig. & 0.028 & 0.769 & \\
\hline
\end{tabular}

Source: own (2016)

The analysis proved that the thin-capitalization rule did not decrease the internal debt of multinational companies operating in Slovenia, as was expected on the basis of the literature and the Slovenian legislator's intention to tighten the rules of interest on relatedparties loans deduction. It turned out that internal indebtedness on average increased. On the basis of our empirical research as well as the last proposal of the Amendment Corporate Income Tax Act, which extended the rule on "sister" companies, we can claim that the Slovenian RIA procedure is not sophisticated enough to facilitate the essential verification of the advisability of a tax rule like thin-capitalization.

\section{Conclusion}

The RIA process helps policymakers think through the consequences of their proposals, improve the quality of advice to Ministers and encourage informed public debate. An effective regulatory impact assessment procedure means ${ }^{38}$ :

- costs and benefits directly related to drawbacks;

- the necessary information and attitudes towards regulatory impact have to be collected through a wide range of consultations;

- strong political support is a precondition for RIA as an important tool that is constantly applied as a part of policy.

In the case of the interest tax shield limitation through the thin-capitalization instrument, none of these pre-conditions were met. The main objective of the paper was to empirically analyse the economic effects of the tax rule implementation as a case of ex-post impact assessment. It turned out that a tightening of the tax rule did not cause a decrease in internal debt ratios. On the contrary, the internal debt ratios increased on average in the observed period, from 2003/04 to 2012/13.

Our ex-post assessment of the tax policy in the case of the interest tax shield is an example of good practice in evaluation of the tax policy instrument. It offers an example of tax instrument evaluation as one of the important factors of tax policy, especially for FDI. We managed to prove that the model for linking the tax policy instrument with financial and investment decisions of FDI is not adequate for Slovenia. The entry into law of the rule on the grounds that it would secure the tax base and consequently tax revenue therefore did not make sense, as these parameters were not an issue in the first place. This appears to

${ }^{38}$ George and Kirkpatrick (2007). 
be even more acute once one notes that the legislator made the rule even more stringent in 2014. Considering our findings as well as literature review, the Slovenian tax policy targeting FDI should be evaluated specifically and multi-dimensionally. Notwithstanding the inadequate RIA procedure, the tax revenues should not be the leading criteria of tax instrument assessment, while there are several factors influencing national economy. It should be evaluated whether the additional tax revenues coming from this (or others) tax instrument compensate for the negative influence of bureaucratic obstacles for FDI, especially if there are no binding legal requirements in EU jurisdiction.

\section{References}

Adelle, C. \& Weiland, S. (2012). Policy assessment. Impact Assessment and Policy Appraisal, 30(1), 25-33.

Adelle, C., Weiland, S., Marquardt, J., Dick, J., González Olivo, D., Rots, G., Wübbeke, J. \& Zasada, I. (2016). Regulatory impact assessment: a survey of selected developing and emerging economies. Public Money and Management, 36(2), 89-96.

Bradley, W. (2015). Tax Prats and Citizen Stakeholders: Professionalism in the Gap Between Tax Priority Setting and Tax Policymaking. Social \& Legal Studies, 24(2), 203.

Buettner, T., Overesch, M., Schreiber, U. \& Wamser, G. (2012). The Impact of Thin Capitalization Rules on the Capital Structure of Multinationals Firms. Journal of Public Economics, 96(11-12), 930-938.

Coletti, P. \& Radaelli, C. M. (2013). Economic rationales, learning, and regulatory policy instruments. Public Administration, 91(4), 1056-1070.

De Francesco, F., Radaelli, M. C. \& Troeger, E. V. (2012). Implementing regulatory innovations in Europe: the case of impact assessment. Journal of European Public Policy, 19(4), 491-511.

European Commission. (2006). Better Regulation - Simply Explained. European Commission, Brussels.

George, C. \& Kirkpatrick, C. (2007). Impact Assessment and Sustainable Development: An Introduction. In George, C. and Kirkpatrick, C. (Eds.). Impact Assessment and Sustainable Development. European Practice and Experience. Cheltenham, Northampton: Edward Elgar Publishing.

Haufler, A. \& Runkel, M. (2012). Firm's Financial Choices and Thin Capitalization Rules under Corporate Tax Competition. European Economic Review, 56, 1087-1103.

Hufbauer, G. C. (1975). U.S. taxation of American business abroad: An exchange of views. Washington: American Enterprise Institute for Public Policy Research.

Jovanović, T. (2014). Did tax reform (thin capitalization rule) from 2005 in Slovenia achieve its aim? Lex localis - journal of local self-government, 12(2), 205-224.

Kouba, L., Mádr, M., Nerudová, D. \& Rozmahel, P. (2016). Policy Autonomy, Coordination or Harmonization in the Persistently Heterogeneous European Union? DANUBE: Law and Economics Review, 7(1), 53-71.

Kovač, M. (2009). Problematika dvojnega obdavčenja dividend, obresti, poslovnih in kapitalskih dobičkov glede na Model OECD in primerjava slovenske ureditve. Podjetje in delo: revija za gospodarsko, delovno in socialno pravo, 35(5), 917-940. 
Kovač, P. (2011). Izbrani vidiki (ne)izvajanja presoje učinkov regulacije v slovenski praksi. Javna uprava, 47(1/2), 129-156.

Morgan, B. (2003). Social Citizenship in the Shadow of Competition. Aldershot: Ashgate. Musgrave, P. (1969). United States Taxation of Foreign Investment: Issues and Arguments. Law School of Harvard University.

Musgrave, P. (2002). International tax differentials for multinational corporations: equity and efficiency considerations. In Musgreve, P. (eds.). Tax Policy in the Global Economy. MPG Books Ltd, Bodmin, Cornwall, p. 98-110.

OECD. (1997). Regulatory Impact Analysis - Best Practice in OECD Countries. Paris: OECD.

OECD. (2003). A Survey on the Role of Taxation in Foreign Direct Investment in South East Europe. Paris: The OECD Tax Centre FOR Tax Policy and Administration with Co-operation with the Investment Compact Team.

OECD. (2008). Building an Institutional Framework for Regulatory Impact Analysis (RIA). Paris: OECD.

OECD. (2009). Indicators of regulatory management systems. Paris: OECD.

OECD. (2015). Regulatory Policy in Perspective: A Reader's Companion to the OECD Regulatory Policy Outlook 2015. OECD Publishing, Paris. Retrieved December 10, 2015, from http://dx.doi.org/10.1787/9789264241800-en.

Overesch, M. \& Wamser, G. (2010). Corporate Tax Planning and Thin-Capitalization Rules: Evidence from a Quasi-Experiment. Applied Economics, 42(5), 563-573.

Owens, J. (1998). Taxation within a Context of Economic Globalization. Amsterdam: IBFD.

Petak, Z. (2015). Evidence-Based Policy Making and the Implementation of Regulatory Impact Assessment in Croatia. Management \& Business Administration. Central Europe, 23(2), 147-162.

Računsko sodišče Republike Slovenije. (2007). Ali v Sloveniji preverjamo učinke predlaganih predpisov na družbo (1). Ljubljana: Revizijsko poročilo.

Računsko sodišče Republike Slovenije. (2012). Ali v Sloveniji preverjamo učinke predlaganih predpisov na družbo (2). Ljubljana: Revizijsko poročilo.

Radaelli, M. C. \& De Francesco, F. (2008). Regulatory Impact Assessment. In Cave, M.; Baldwin, R.; Lodge M. (eds.). The Oxford Handbook of Regulation. Oxford: Oxford University.

Rakar, I. (2005). Ocenjevanje vplivov predpisov. Revija Uprava, 3(1), 51-81.

Ramb, F. \& Weichenrieder, A. J. (2005). Taxes and the Financial Structure of German Inward FDI. Review of World Economics, 141(4), 670-692.

Thuronyi, V. (1998). The Law Design and Drafting. Washington D.C.: International Monetary Fund.

Wamser, G. (2014). The Impact of Thin-Capitalization Rules on External Debt Usage - A Propensity Score Matching Approach. Oxford Bulletin of Economics and Statistics, 76(5), 764-781.

Weichenrieder, A. (2009). Profit shifting in the EU: evidence from Germany. International Tax Finance, 16(3), 281-297. 
ZDDPO-2, The Corporate Income Tax Act, Official Gazette of the Republic of Slovenia (Uradni list Republike Slovenije), No. 117/06, 56/08, 76/08, 5/09, 96/09, 43/10, 59/11, 24/12, 30/12. 